\title{
VEGETABLE CONSUMPTION PATTERNS IN YAOUNDÉ, CAMEROON
}

\section{Kamga $\mathbf{R}^{1^{*}}$, Kouamé $\mathrm{C}^{2}$, and $\mathbf{E}$ Akyeampong ${ }^{3}$}

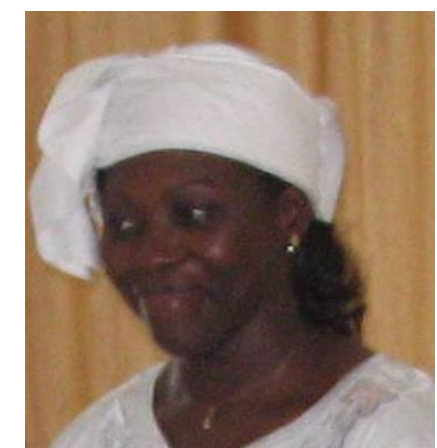

\section{Regine Tchientche Kamga}

*Corresponding author email: regine.kamga@worldveg.org

${ }^{1}$ AVRDC - The World Vegetable Center, Liaison office Cameroon. P.O. Box 2008 Messa, Yaoundé, Cameroon.

2 ICRAF- The World Agroforestry Center, ICRAF/MARS V4C project. P.O. Box 2024 San Pedro, COTE D'IVOIRE.

${ }^{3}$ P.O Box KS10883, Kumasi, Ghana. 


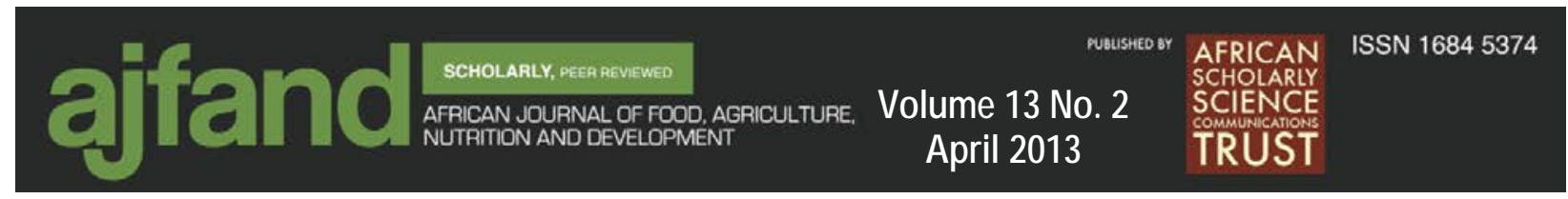

\begin{abstract}
A survey was conducted in August and September 2008 in Yaoundé, Cameroon to assess vegetable consumption attitudes, constraints and factors that stimulate households' consumption. Stratified sample based on district size, socioeconomic status and ethnics groups were used. Three hundred households were interviewed using a questionnaire and there were four times as many women as men in the sample. Data were analyzed using SNAP. More than $80 \%$ of the respondents were educated at the secondary (54\%) and tertiary (30\%) levels. The respondents were generally the wife (35\%) or children (30\%), and sometimes the husband (20\%). More than $50 \%$ of the respondents were landlords living in their own homes and the rest were tenants. On average, the population of Yaoundé consumed vegetables frequently (2 to 4 times per week). Tomato, onion, carrot, and chili pepper were the most preferred exotic vegetables while bitter leaf $(>80 \%)$ and okra $(>70 \%)$, were the most preferred traditional vegetables. Attitudes towards vegetables varied according to socioeconomic and ethnic group. Main constraints to vegetable consumption were preparation time for respondents in the upper class (30\%) and social taboos (amaranth is an ominous crop and can cause impotency in men; okra can inhibit the traditional treatment of some diseases) for the middle and lower classes. Freshness, wholesomeness, and color of the fruit or leaves determined the decision to purchase vegetables. Diversification of diet which is good for health, the preference of family members, and taste were the main reasons for consuming vegetables. Taste, degree of sliminess (okra), and smell after cooking were factors that increased satisfaction during consumption. Two-thirds of the respondents knew the benefits of vegetable consumption but their knowledge was not specific and is influenced by social taboos. Willingness to pay for processed traditional vegetables was higher among respondents in the upper income class (56.9\%) than the lower (45.8\%) and middle (37.1\%) classes. The study revealed a need to further promote the consumption vegetables and inform consumers of their nutritional benefits.
\end{abstract}

Key words: vegetables, consumption, nutrition, vitamins, minerals 


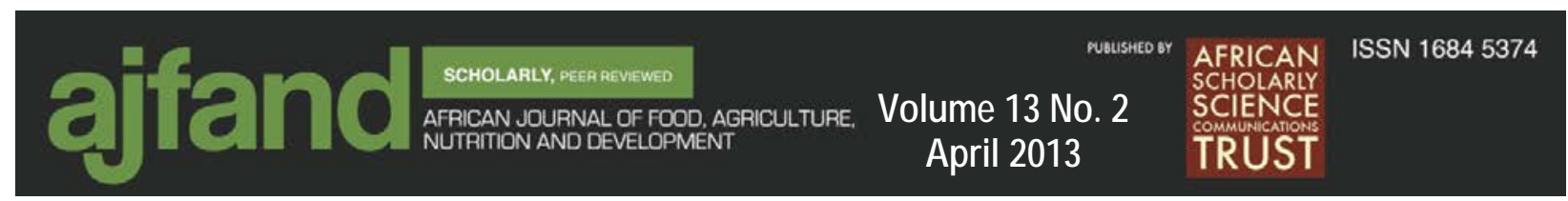

\section{RESUME}

Des facteurs qui affectent la consommation des légumes dans la ville de Yaoundé, Cameroun, ont été évalués dans une enquête de 300 ménages choisis sur la base d'un échantillonnage stratifié et analysés en utilisant le logiciel Snap survey. L'échantillon est 4 fois plus constitué de femme que d'homme. Plus de $80 \%$ de l'échantillon est instruit avec un niveau d'éducation secondaire (54\%) et tertiaire (30\%). Les répondants étaient le plus souvent des épouses (35\%) ou des enfants (30\%) et parfois des chefs de famille (20\%). Plus de $50 \%$ des répondants étaient propriétaires de leurs maisons et le reste était des locataires. En moyenne, les légumes sont consommés deux à quatre fois par semaine. La tomate, l'oignon, la carotte et le poivron étaient les légumes exotiques les plus préférés alors que le ndolé ( $>80 \%$ ) et le gombo (> $70 \%$ ) étaient les légumes traditionnels les plus appréciés. Les attitudes des consommateurs envers des légumes changeaient selon le groupe ethnique et socio-économique. Les contraintes principales à la consommation des légumes étaient le temps de préparation pour les répondants de la haute classe (30\%) et pour les répondants de la classe moyenne et la basse classe, ce sont les tabous tels que l'amarante serait un légume de mauvais augure pouvant causer l'impuissance chez les hommes, tout comme le gombo qui peut empêcher le traitement traditionnel d'un certain nombre de maladies. La fraîcheur, l'état sanitaire et la couleur du fruit ou des feuilles sont les critères influençant la décision d'achat des légumes. La santé, les préférences des membres de la famille, et le goût étaient les raisons principales pour consommer les légumes. Le goût, le degré de viscosité (gombo) et l'odeur après cuisson étaient les facteurs qui augmentent la satisfaction du consommateur. Deuxtiers des répondants ont affirmé qu'ils connaissent les avantages de la consommation des légumes mais leur connaissance était vague. Le consentement à payer les légumes traditionnels transformés était plus élevé chez des répondants de la classe aristocratique (56.9 \%) que la basse classe $(37.1 \%)$ et la classe moyenne (45.8 \%). L'étude a révélé un besoin de promouvoir la consommation et les avantages nutritionnels des légumes.

Mots clés : Légumes, consommation, nutrition humaine, vitamines et minéraux. 


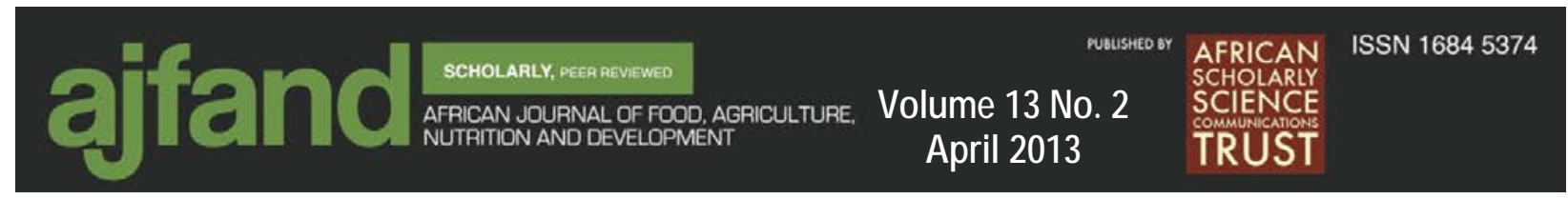

\section{INTRODUCTION}

Vegetables are important sources of vitamins and minerals for the human diet. The World Health Organization (WHO) reported in 2002 that a diet lacking in fruits and vegetables is a major independent risk factor for non-communicable diseases such as cardiovascular disease and cancer [1]. In sub-Saharan Africa, it is estimated that by 2020 non-communicable diseases will outstrip communicable diseases as a cause of death [2]. Worldwide, mortality attributable to insufficient fruit and vegetable intake was estimated at 2.7 million deaths yearly. The consultation of FAO/WHO on Diet, Nutrition, and the Prevention of Diseases recommends a minimum daily intake of $200 \mathrm{~g}$ of vegetables or about $73 \mathrm{~kg} /$ year/person [3].

The production of vegetables in Africa is far behind the global average: annual per capita production is approximately $50 \mathrm{~kg}$, which is less than half of the production in all other regions of the world. The vegetable production area in sub-Saharan Africa (about 2.5 million ha) has not changed since 1990, while global vegetable area is increasing (more than 50 million ha in 2005, with about 20 million ha in India alone) [4]. Per capita vegetable consumption in sub-Saharan Africa is lower than the rest of the world, and is declining. In sub-Saharan Africa, Nigeria had the highest vegetable consumption at $61.3 \mathrm{~kg} /$ capita/year [5].

Malnutrition is a serious health problem in Cameroon. Most clinical forms are protein-calorie malnutrition (PCM), nutritional anemia, and vitamin A deficiency [6, $7,8]$. Protein-calorie malnutrition affects all groups, particularly infants and young children. One out of every four children (24.4\%) under 5 years suffered from chronic malnutrition [6]; a more recent report indicated that $35.4 \%$ children under 5 years are stunted and $15 \%$ are underweight because of chronic malnutrition [9]. To tackle the challenge of nutritional insecurity, new nutritional sources, including vegetables and diet diversification opportunities must be explored. This study examined the factors that determine vegetable consumption behavior in Cameroon by socio-economic and ethnic group. Using a representative household survey, this study analyzed vegetable consumption patterns in Yaoundé, assessed respondents' knowledge of the importance of vegetables and determined consumers' Willingness To Pay (WTP) for processed leafy vegetables.

\section{METHODOLOGY}

\section{Study site}

Yaoundé was chosen as study site because of its cosmopolitan population, the high purchase power of this population and existence of a peri urban and urban vegetable production. Yaoundé is located in Southern Cameroon specifically in the center region between latitude $3^{\circ} 47^{\prime}-3^{\circ} 56^{\prime} \mathrm{N}$ and longitude $11^{\circ} 10^{\prime}-11^{\circ} 45 \mathrm{E}$ at an altitude of $750 \mathrm{~m}$ covering a total area of $256 \mathrm{~km}^{2}$. The annual rainfall pattern is bimodal, with an average of $1600 \mathrm{~mm}$ and an average annual temperature of $24^{\circ} \mathrm{C}$. The population of Yaoundé is approximately 2 million. 


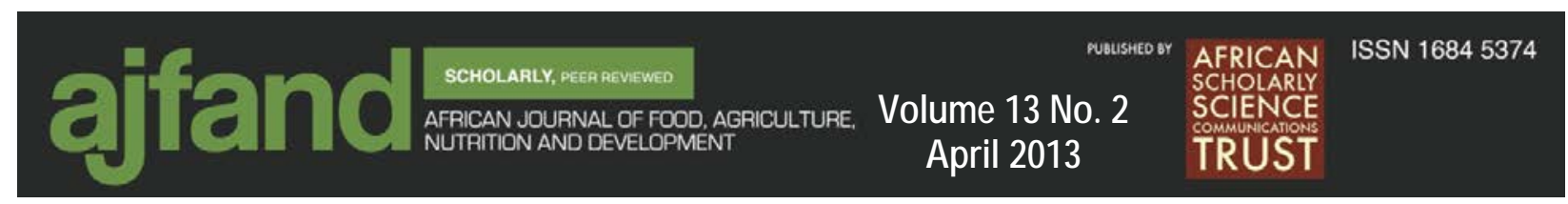

\section{Data collection and sampling procedure}

Three hundred households were selected by stratified sampling based on district size, socio-economic status, and ethnic groups. They were interviewed from AugustSeptember 2008 using a pre-tested questionnaire that included socio-demographic information, education level of the respondent, nature of occupation of household head, frequency of vegetable consumption, Willingness to pay processed vegetable and knowledge on the benefit of vegetable nutrition as major components. The tools used to establish the socio economic subdivision were the total household size, the family income and wealth, the type of housing and the area of residence. Low income class are people with income less or equal to the official basic salary, living on less than US\$1 per day in vulnerable conditions while high income class are people leaving in residential towns, mostly involved in business and enjoying high comfort and security.

\section{Data analysis}

Information from interviews was entered and analyzed using Snap 9 survey software [10]. Snap survey software is powerful, intuitive software for questionnaire design, publishing, data collection and analysis. Parameters were defined following the sequence of the questions in the questionnaire. Frequencies of similar answers were grouped and compared between socio economic and ethnic groups by crosstabulation. Tables and graphics could therefore be drawn using Excel.

\section{RESULTS}

\section{Socio demographic information}

The households had four times as many women than men (Fig. 1). More than $50 \%$ of the respondents were landlords and the rest were tenants. About $44.4 \%$ of the respondents were married while $49.2 \%$ were single. More than $80 \%$ of the respondents were educated up to the secondary (54\%) and tertiary (30\%) levels. The respondents were generally composed of; wife (35\%) or children (30\%), and sometimes the husband (20\%). 

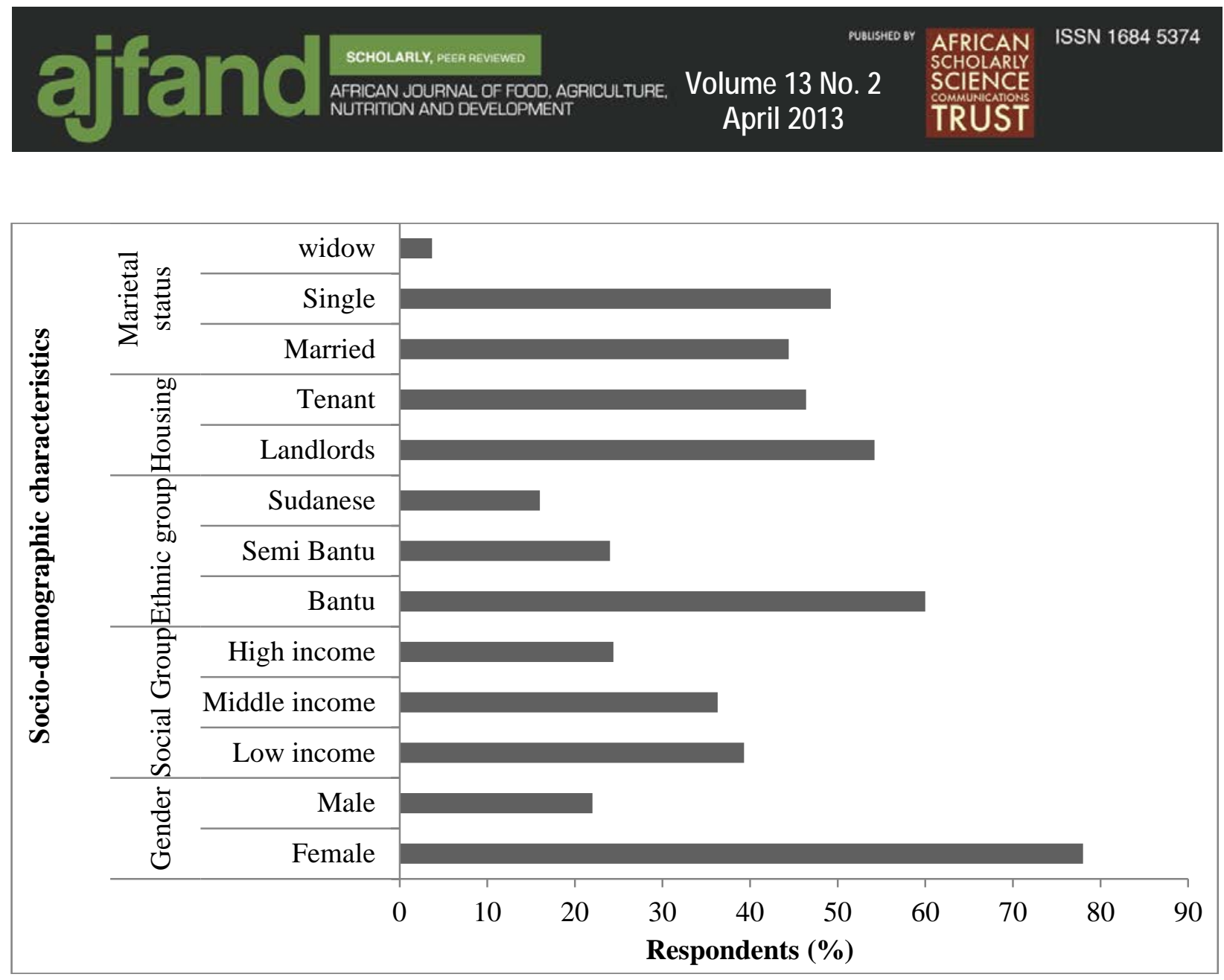

Figure 1: Socio-demographic characteristics of the respondents

\section{Consumption characteristics}

\section{Frequency of vegetable consumption}

More than half of the households consume vegetables more than once a week. Semi Bantu (64\%) consume vegetables more than the other ethnic groups (Table 1). Respondents were composed of 60\% Semi Bantu, 24\% Bantu and 16\% Sudanese.

The percentage of high and low income people who consume vegetables 2-4 times/week is approximately equal (Table 1). Respondents were composed of $24.4 \%$ of high income class, $36.3 \%$ of Middle income class and $39.3 \%$ of low income class.

\section{Preferences by socio economic and ethnic group}

For exotic vegetables, all socio-economic groups preferred tomato, onion, carrot, and hot pepper. Okra and bitter leaf were the most preferred indigenous vegetable across all socio-economic groups (Table 2).

By ethnic group, nightshade was the second most preferred indigenous vegetable for the Bantu and Semi Bantu, while amaranth and jute mallow were the second most preferred indigenous vegetables for the Sudanese (Table 3). 


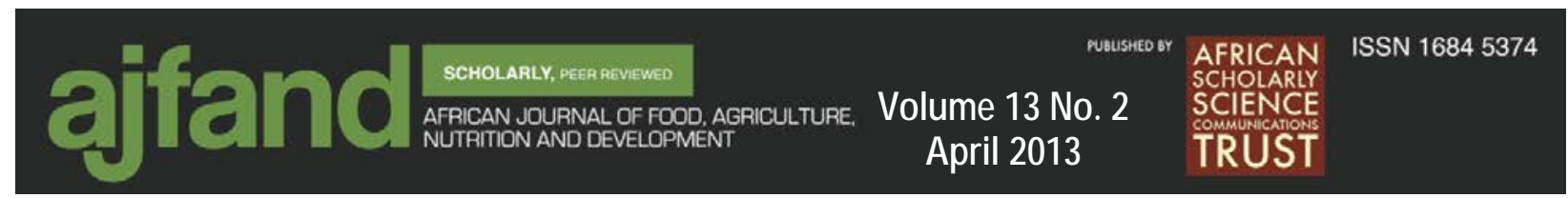

Other indigenous vegetables consumed were African eggplant, cassava leaves, and melon leaves.

\section{Motivations and barriers to vegetable consumption}

Factors cited by consumers for purchasing vegetables included; freshness, wholesomeness, and color of the fruit or leaves. Diversifying diets to ensure good health, preferences of different family members, cultural preferences, and the taste of different vegetables are the main reasons that motivated vegetable consumption. The study shows that taste, degree of sliminess (okra), and smell after cooking are factors that increase consumers' satisfaction.

The obstacles to vegetable consumption are social taboos and the time spent to prepare and cook vegetables. High income class viewed vegetable preparation and cooking as a waste of time. Some of the often-mentioned taboos and beliefs include: amaranth is an ominous crop and can cause impotency in men; okra can inhibit the traditional treatment of some diseases (asthma and epilepsy) and inhibit the protection effect of the traditional body scarification; nightshade can cause skin allergies; and roselle can cause loss of male virility.

\section{Knowledge of the value of vegetables}

The majority $78.3 \%$ of respondents stated that they are aware of the benefits of vegetable consumption, but their knowledge is empirical and not specific. However, as regards to problems of not consuming enough vegetables, respondents were almost evenly split.

The data indicate that the importance of vegetable consumption is not genderspecific. More than $90 \%$ of the respondents agree that vegetables are important for women, children, and men. The results showed that more than $80 \%$ of respondents think vegetables are not inferior food and are good for everyone irrespective of the social class (Table 4). People believe that processing decreases the value of the food; about $80 \%$ of respondents affirmed that fresh vegetables contain more nutrients than dry vegetables. Respondents were split almost evenly on the idea that cooking vegetables for a long time can cause the loss of nutrients (Table. 4).

\section{Willingness to Pay (WTP)}

The majority of the respondents in all socio-economic groups buy their vegetables in the nearest market. Approximately half of the higher income class surveyed buys their vegetables in a covered market, compared to $12.9 \%$ of low income class (Fig. 2). 

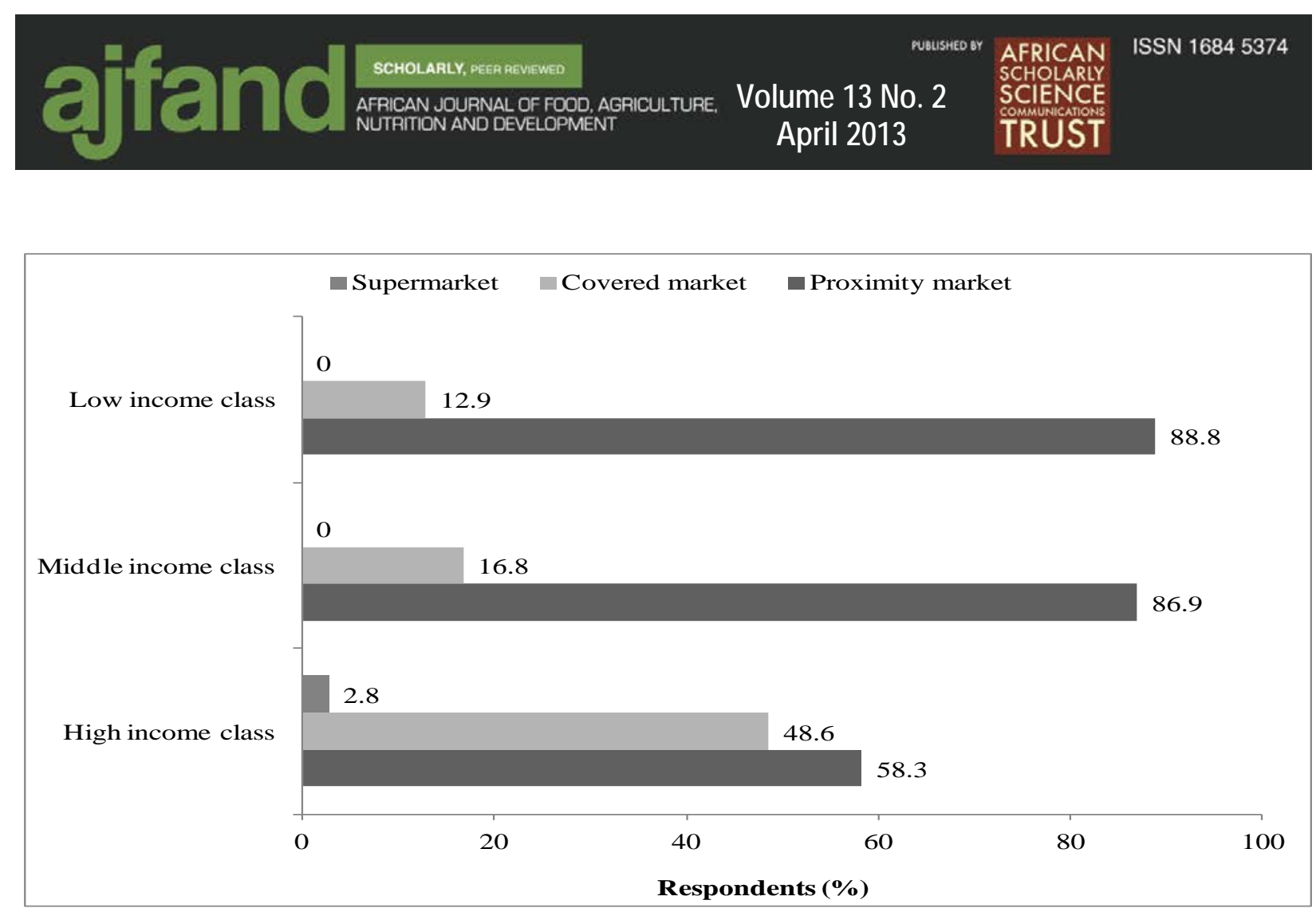

Figure 2: Market where respondents buy vegetables

Low income class is more willing to purchase processed indigenous vegetables, while the high income and middle class are not (Fig. 3).

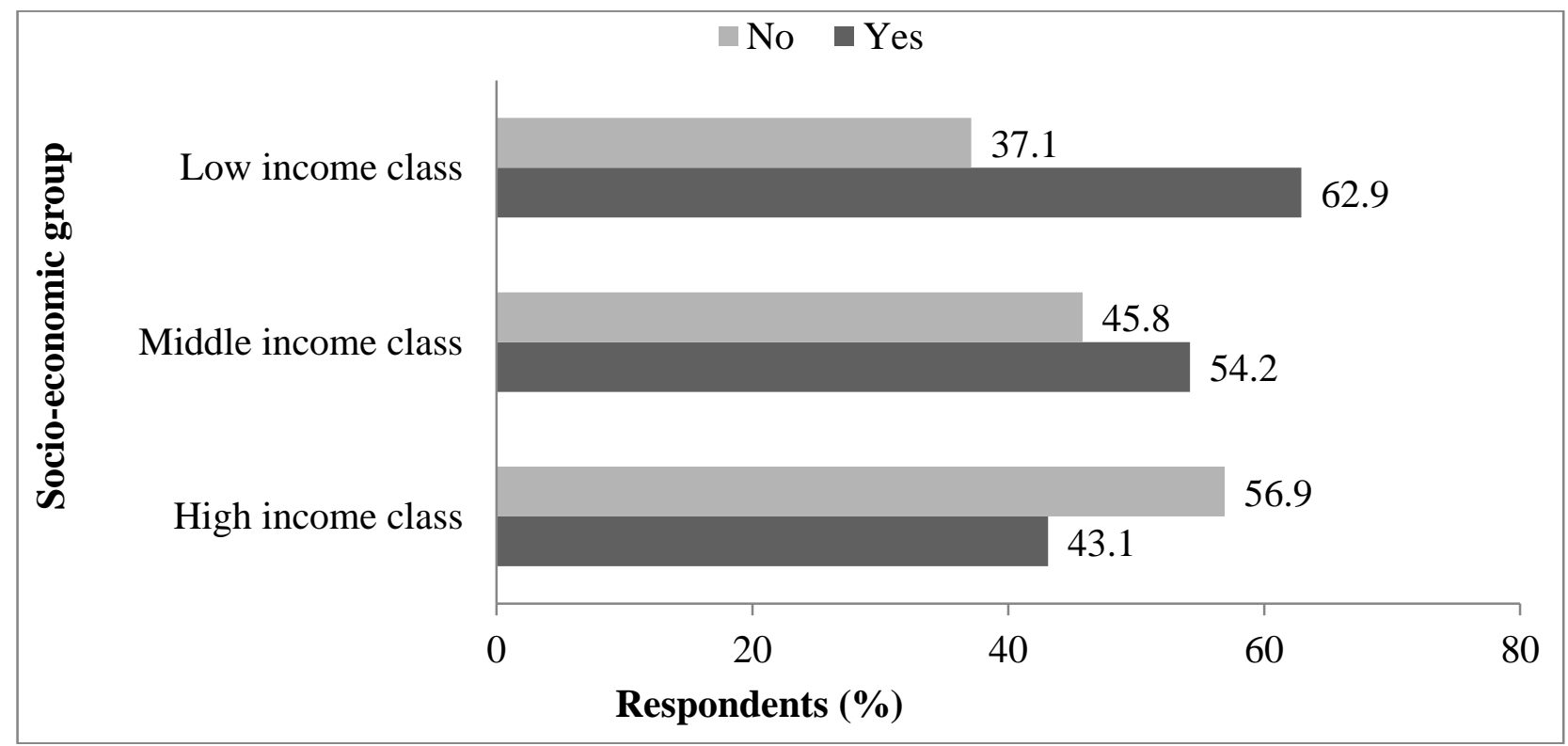

Figure 3: Willingness to Pay (WTP) for processed indigenous vegetables 


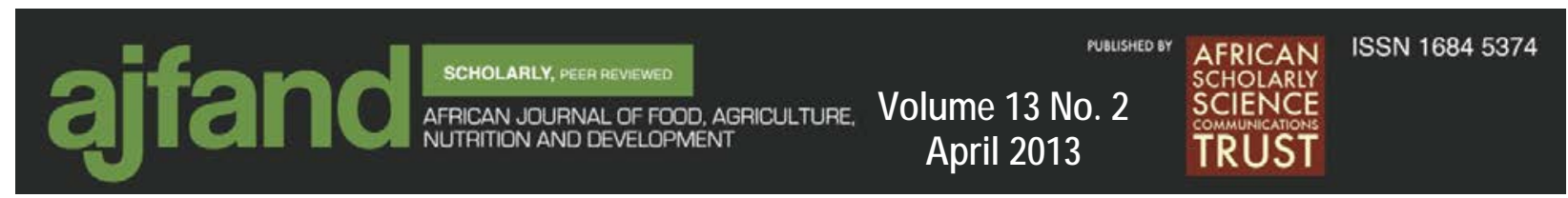

\section{DISCUSSION}

Price can influence vegetable consumption if supplies are limited, as sometimes occurs with transportation constraints [11]. In Yaoundé, however, leafy vegetables are produced in urban and peri-urban areas to supply the markets [12]. Peri-urban vegetables are considered to be fresher by consumers [13]. The urban and peri urban production of leafy vegetables year-round can thus satisfy consumer demand for fresh vegetables. However, this study revealed that consumers do not care about the origin of the products; they feel this is the seller's responsibility. Consumer preferences also explain the variation of consumption frequency among socioeconomic and ethnic groups, because preferences may be household specific, cultural or specific to individuals [14]. This study shows the Semi Bantu do not consume much jute mallow, while this vegetable is one of the top species preferred by Sudanese and Bantu.

Willingness to pay for processed vegetables is also low in Vietnam, although frozen vegetables are available in a few supermarkets; they are not widely consumed [15]. People preferred to buy their vegetables mainly at street markets. The low credibility of quality claims on packaging and the higher prices of supermarkets may hinder sales of processed vegetables; consumers give little credibility to the "clean vegetables" labels used by supermarkets [13].

Despite the reasonable frequency of vegetable intake found in this study, the quantities consumed remain low and cooking methods are less efficient, causing the loss of nutrients. Anemia is one form of malnutrition that affects all groups in Cameroon, mostly infants and women of childbearing age. A study in Cameroon, found that men consumed more vegetables than women [16]. Irrespective of sex, the authors showed that infants (0-4 year) and adolescents consumed fewer vegetables than recommended. The national prevalence of anemia was reported to be almost 57 $\%$ among children under 5 year old with rates as high as $67 \%$ in certain regions including the study site [17]. Anemia is also a major contributor to maternal mortality, anemia rate among pregnant women exceed 52\% [17]. Vegetables are the most affordable and sustainable dietary source of vitamins, trace elements, and other bioactive compounds. Improved vegetable production and consumption is thus regarded as the most direct, low-cost method for urban and rural poor to increase micronutrients in their diets [18].

\section{CONCLUSION}

In conclusion, the results have shown that majority of respondents consumed vegetables two to four times per week. Tomato, onion, and pepper are consumed every day. Price and availability did not significantly affect vegetable consumption. From the trend seen in this study, freshness, consumer preferences, and taste determines the choices consumers make about which vegetables to purchase and consume. Appropriate postharvest technologies should be applied to satisfy the willingness to pay for processed indigenous vegetables. Promoting the nutritional 
importance of vegetables in Cameroon could increase consumption and improve the nutritional status of all income groups. Promotion of home production could also be another potential strategy to increase consumption at household level. The influence of social taboos that hinder increased consumption of vegetables will need to be addressed through nutrition education and extension communication programs. Such programs will also improve nutritional knowledge-awareness of which was rated low by respondents in this study - to further enhance the consumption of vegetables.

\section{ACKNOWLEDGEMENTS}

The authors thank AVRDC-The World Vegetable Center for the staff time spent to improve this paper. 
Table 1: Frequency of vegetable consumption by socio economic and ethnic groups

\begin{tabular}{|c|c|c|c|c|c|}
\hline & $\begin{array}{l}\text { Rarely (< } \\
1 \text { time a } \\
\text { week) }\end{array}$ & $\begin{array}{l}\text { Occasionally } \\
\text { (1-3 times a } \\
\text { month) }\end{array}$ & $\begin{array}{l}\text { Infrequently } \\
\text { (once a } \\
\text { week) }\end{array}$ & $\begin{array}{l}\text { Frequently } \\
\text { (2-4 times a } \\
\text { week) }\end{array}$ & $\begin{array}{l}\text { Very } \\
\text { frequently } \\
\text { (almost every } \\
\text { day) }\end{array}$ \\
\hline \multicolumn{6}{|l|}{ A. Ethnic group } \\
\hline Sudanese & 2.2 & 0 & 15.2 & 54.9 & 28.3 \\
\hline Semi bantu & 5.8 & 2.9 & 23.2 & 63.8 & 4.3 \\
\hline Bantu & 5.6 & 6.2 & 24.7 & 51.7 & 11.8 \\
\hline \multicolumn{6}{|c|}{ B. Socio-economic group } \\
\hline Low income revenue & 5.2 & 2.6 & 22.4 & 56.9 & 12.9 \\
\hline Middle income revenue & 5.6 & 5.6 & 24.3 & 51.4 & 13.1 \\
\hline High income revenue & 4.2 & 5.6 & 20.8 & 56.9 & 12.5 \\
\hline
\end{tabular}


Table 2: Indigenous vegetables preferences by socio-economic group

\begin{tabular}{l|ccc}
\hline \multirow{2}{*}{ Vegetables } & \multicolumn{3}{|c}{ Respondents by socio-economic group (\%) } \\
\cline { 2 - 4 } Eggplant & High income class & Middle income class & Low income class \\
Okra & 36.1 & 15.9 & 18.1 \\
Amaranth & 70.8 & $\mathbf{7 0 . 2}$ & $\mathbf{8 5 . 3}$ \\
Nightshade & 72.2 & 67.3 & 71.6 \\
Bitterleaf & 68.1 & 70 & 74.1 \\
Jute mallow & $\mathbf{8 1 . 9}$ & 51.4 & 58.6 \\
Egusi & 61.1 & 53.3 & 56 \\
Others & 66.7 & 45.8 & 36 \\
\hline
\end{tabular}


Table 3: Indigenous vegetables preferences by ethnic group

\begin{tabular}{l|ccc}
\hline \multirow{2}{*}{ Vegetables } & \multicolumn{3}{|c}{ Respondents by Ethnic group (\%) } \\
\cline { 2 - 4 } & Bantu & Semi Bantu & Sudanese \\
\hline Eggplant & 25.8 & 13 & 15.2 \\
Okra & $\mathbf{7 4 . 2}$ & $\mathbf{7 8 . 3}$ & $\mathbf{8 0 . 4}$ \\
Amaranth & $\mathbf{7 1 . 9}$ & 60.9 & $\mathbf{7 6 . 1}$ \\
Nightshade & 73 & $\mathbf{7 3 . 9}$ & 60.9 \\
Bitterleaf & 61.8 & 59.4 & 65.2 \\
Jute mallow & 59.6 & 34.8 & $\mathbf{7 6 . 1}$ \\
Egusi & 53.4 & 68.1 & 43.5 \\
Others & 30.9 & 26.1 & 26.1 \\
\hline
\end{tabular}


Table 4: Some opinions concerning vegetable consumption

\begin{tabular}{|c|c|c|c|c|c|}
\hline & $\begin{array}{l}\text { Agree } \\
\text { perfectly (\%) }\end{array}$ & $\begin{array}{l}\text { Agree } \\
(\%)\end{array}$ & $\begin{array}{l}\text { Not sure } \\
(\%)\end{array}$ & $\begin{array}{l}\text { Disagree } \\
(\%)\end{array}$ & $\begin{array}{l}\text { Disagree } \\
\text { Absolutely (\%) }\end{array}$ \\
\hline $\begin{array}{l}\text { Consumption of vegetable is } \\
\text { also important for women, } \\
\text { children and men }\end{array}$ & 62.7 & 34.2 & 2 & 1 & 0 \\
\hline $\begin{array}{l}\text { Vegetable is an inferior food } \\
\text { that are only good for people } \\
\text { who don't have money or } \\
\text { enough food }\end{array}$ & 5.8 & 11.2 & 1.7 & 41.4 & 40 \\
\hline $\begin{array}{l}\text { Fresh vegetable contain more } \\
\text { nutrients than dry vegetable }\end{array}$ & 26.8 & 52.9 & 17.3 & 1.7 & 1.4 \\
\hline $\begin{array}{l}\text { Cooking vegetable for a long } \\
\text { time can cause the loss of } \\
\text { nutrients }\end{array}$ & 9.8 & 45.1 & 30.5 & 12.9 & 1.4 \\
\hline
\end{tabular}




\section{REFERENCES}

1. WHO. World Health Organization. World Health Report Reducing risks, promoting healthy life. Geneva, World Health Organization, Geneva. 2002.

2. Murray CL and AD Lopez Global mortality, disability and the contribution of risk factors. Global Burden of Disease Study. 1997; 349:1436-42.

3. Fantauzzo L Meatless Mondays movement pushes veggies on Pinoys, GMA News beta version, www.gmanetwork.org, GMA Network Inc., 2011.

4. AVRDC. Vegetables for life: Confronting the crisis in Africa. AVRDC - The World Vegetable Center, Taiwan. 2003.

5. Ganry J Current Status of Fruits and Vegetables Production and Consumption in Francophone African Countries - Potential Impact on Health, Proc. IInd IS on Human Health Effects of F\&V Ed.: B. Patil Acta Hort, ISHS 2009: 841: 249-255.

6. Balepa $\mathbf{M}$, Fotso $\mathbf{M}$ and $\mathbf{B}$ Barrère Enquête démographique et de santé. Marco Int. Inc. Columbia, Maryland, USA. 1992.

7. Fotso M, Ndonou R, Libitie PR, Tsafack M, Wakou R and A Ghapoutsa Enquête démographique et de santé. Cameroun 1998 (DAS). Bureau Central des Recensements et des études de population, Ministère des Investissements Publiques et de l’Aménagement du Territoire. Yaoundé, Cameroun. 1998.

8. MINSANTE/UNICEF. Cameroun enquête national sur la carence en vitamine A et l'anémie, Minsanté/Unicef publication. 2001.

9. World Health Organization. World Health Statistics Report 2009. WHO Library Cataloguing-in-Publication Data. 2009.

10. Snap survey software 9 Snap-Benelux Solus - 22 Avenue des Hirondelles 1780 Wemmel Belgique, tel. 027129555 - 0473564288 (gam) - fax 02 7129559 - www.snap-benelux.be, 2009. Accessed 23 March 2012.

11. Hart AD, Azubuike CU, Barimala IS and SC Achinewhu Vegetable Consumption Patterns of Households in Selected Areas of the Old Rivers State in Nigeria. African Journal of Food Agriculture and Nutritional Development. 2005: 5 (1).

12. Gockowski J, Mbazo'o J, Mbah G and FT Moulende African traditional leafy vegetables and the urban and peri-urban poor. Food Policy 2003; 28: 221-235. 
13. Bridier BE Etude de la perception de la qualité des légumes par les consommateurs de Hanoi (Vietnam). Cas particulier de la qualité sanitaire. ESAT "Développement agricole tropical. Option: Valorisation des productions". Montpellier, CNEARC. 2000: 149.

14. Ruel TM, Minot $\mathbf{N}$ and $\mathbf{L}$ Smith Pattern and Determinants of Fruit and Vegetable consumption in Sub-Saharan Africa: A multitude comparison. International Food Policy Research institute, Washington DC, USA. 2005.

15. IFPRI. International Food Policy Research Institute. Vietnam's fruit and vegetable sector: raising rural incomes by improving post-harvest activities. Executive summary: 2002: 21.

16. Lock K, Pommerlau J, Causer L, Altman RD and M McKee The global burden attributable to low consumption of fruits and vegetables: Implication for the global strategy on diet. Bulletin of the World Health Organization. 2005; 83:100-108.

17. HKI. Helen Keller International. Cameroun National survey on vitamin A deficiency and anemia. 2000.

18. FAO. United Nations Food and Agriculture Organization. Home-based vegetable gardens and other strategies to overcome micronutrient malnutrition in developing countries. 2003; 32: 17-23. 